\title{
Modeling of Compressive Strength Parallel to Grain of Heat Treated Scotch Pine (Pinus sylvestris L.) Wood by Using Artificial Neural Network
}

\section{Modeliranje tlačne čvrstoće paralelno s vlakancima toplinski obrađenog drva škotskog bora (Pinus sylvestris L.) s pomoću umjetne neuronske mreže}

\author{
Professional paper • Stručni rad \\ Received-prispjelo: 30. 9. 2014. \\ Accepted-prihvaćeno: 6. 11. 2015. \\ UDK: $630 * 812.72$ \\ doi:10.5552/drind.2015.1434
}

In this study, the compressive strength of heat treated Scotch Pine was modeled using artificial neural network. The compressive strength (CS) value parallel to grain was determined after exposing the wood to heat treatment at temperature of 130,145, 160, 175, 190 and $205^{\circ} \mathrm{C}$ for 3, 6, 9, 12 hours. The experimental data was evaluated by using multiple variance analysis. Secondly, the effect of heat treatment on the CS of samples was modeled by using artificial neural network (ANN).

Key words: wood, heat treatment, Artificial Neural Network, compressive strength

Rad prikazuje numeričku proceduru za analizu struktura izrađenih od kompleksnih laminata. PostuU radu se obrađuje modeliranje tlačne čvrstoće toplinski obrađenog drva škotskog bora uz pomoć umjetne neuronske mreže. Vrijednost tlačne čvrstoće (CS) paralelno s vlakancima određena je nakon toplinske obrade pri temperaturi 130, 145, 160, 175, 190 i $205{ }^{\circ} \mathrm{C}$ tijekom 3, 6, 9 i 12 sati. Eksperimentalni podaci analizirani su primjenom višestruke analize varijance. Osim toga, učinak toplinske obrade na tlačnu čvrstoću uzoraka modeliran je uz pomoć umjetne neuronske mreže (ANN).

Ključne riječi: drvo, toplinska obrada, umjetna neuronska mreža, tlačna čvrstoća

\footnotetext{
Author is professor at Ondokuz Mayis University, Engineering Faculty, Department of Industrial Engineering, Samsun, Turkey. ${ }^{2}$ Authors are professors at Karabük University, Technical Education Faculty, Department of Furniture and Decoration Education, Karabük, Turkey. ${ }^{\mathrm{c} A u-}$ thor is professor at Bülent Ecevit University, Engineering Faculty, Department of Computer Engineering, Zonguldak, Turkey.

${ }^{1}$ Autor je profesor Sveučilišta Ondokuz Mayis, Fakultet inženjerstva, Odjel za industrijsko inženjerstvo, Samsun, Turska. ${ }^{2}$ Autori su profesori Sveučilišta Karabük, Fakultet tehničkog obrazovanja, Odjel za namještaj i uređenje interijera, Karabük, Turska. ${ }^{3}$ Autor je profesor Sveučilišta Bülent Ecevit, Fakultet inženjerstva, Odjel za računalno inženjerstvo, Zonguldak, Turska.
} 


\section{INTRODUCTION}

\section{UVOD}

Heat treatment is a wood modification method used to improve some properties of the wood. Heat treatment also helps to diminish equilibrium moisture content of wood samples (Mazela et al., 2004). The temperature level and duration of heat treatment mostly change from 180 to $280{ }^{\circ} \mathrm{C}$ and from $15 \mathrm{~min}$ to $24 \mathrm{~h}$ depending on the heat treatment process, sample size, wood species, moisture content of the sample and the properties of the final product (Kandem et al., 2002; Militz et al., 2002).

The values of hardness and strength of wood decrease with the increase of heat treatment parameters (temperature and duration). These effects are achieved especially when heat treatment is carried out for a long time. The strength values of wood most affected by heat treatment are impact and static bending strengths, while the least affected property is the modulus of elasticity (Korkut et al., 2008).

Artificial neural network (ANN) is a computational model based on the information processing system of the human brain. ANN model is composed of three layers, which are called input layer, hidden layer and output layer. This network structure is also called MLP (Ișeri and Karlık, 2009).

While the input layer receives the initial values of the variables, the output layer shows the results from the network for the input. The hidden layer carries out the operation design to achieve the output. The number of neurons in the input layer must correspond to the number of entry variables, and the output layer must have as many neurons as the number of outputs manufactured by the network. However, there is no rule to allow prior decisions to indicate the number of neurons contained in the hidden layer or sublayer. The only way to obtain the hidden layer is by a process of trial and error (Sha, 2007).

Artificial neural network has been widely used in many wood industries, such as in the wood identification system (Tou et al., 2007; Khalid et al., 2008; Estaben et al., 2009a; Junior et al., 2006) in the suggestion on the application of geodesy (Arslan et al., 2007), in the prediction of wood dielectric loss factor (Avramidis et al., 2006), in the calculation of wood thermal conductivity (Xu et al., 2007), in predicting fracture toughness of wood (Samarasinghe et al., 2007), in the evaluation of strength of wood timbers (Tanaka et al., 1996), in the prediction of bending strength and stiffness in western hemlock (Shawn et al., 2007), in the prediction of particle- board mechanical properties (Fernández et al., 2008), in the optimization of process parameter in a particleboard manufacturing process (Cook et al., 2000), in the detection of structural damage in medium density fiberboard panels (Long et al., 2008), in the prediction of modulus of rupture and modulus of elasticity of flake board (Yapıcı et al., 2009). It has also been applied to obtain the hygroscopic equilibrium points (Avramidis and Iliadis, 2005), to classify wood defects (Drake and Packianather, 1998), to determine the internal bond values of particleboard (Cook and Chiu, 1997; Fernandez et al., 2008), and in statistical process control in the manufacture of particleboard (Estaben et al., 2009b).

In this study, compression strength parallel to grain of heat treated Scotch pine wood samples was examined experimentally, and then artificial neural network (ANN) system was designed for predicting this value.

\section{MATERIALS AND METHODS} 2. MATERIJALI I METODE

Scotch pine wood (Pinus sylvestris L.) was chosen randomly from timber merchants of Karabuk, Turkey. In the selection of wood material, special emphasis was on the properties of non-deficient, proper, knotless, normally grown wood (without zone line, reaction wood, decay, insect and mushroom damages). The selected specimens were cut to sizes of $20 \times 20 \times 300$ $\mathrm{mm}$ and they were exposed to heat treatment at 130 , $145,160,175,190$ and $205^{\circ} \mathrm{C}$ for $3,6,9$, and 12 hours. Then, they were resized to $20 \times 20 \times 30 \mathrm{~mm}$. The compressive strength values were determined from test samples according to TS 2595 standard (TS 2595).

\subsection{Statistical analyses \\ 2.1. Statističke analize}

Data for each test were statistically analyzed. Analysis of variance was used to test the significance between factors and levels. When the analysis of variance pointed a significant difference among the factors and levels, a comparison of the means was conducted employing a Tukey test.

\subsection{Design of artificial neural network for CS value \\ 2.2. Dizajn umjetne neuronske mreže za tlačnu} čvrstoću

In this study, the effects of heat treatment conditions on compressive strength parallel to grain of scotch pine wood were determined experimentally. Secondly, artificial neural network model was applied

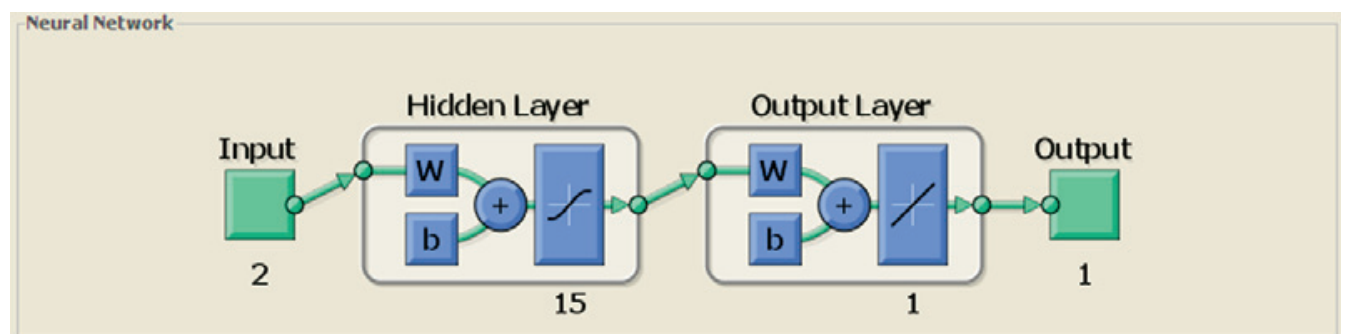

Figure 1 Design of ANN model

Slika 1. Dizajn modela umjetne neuronske mreže (ANN) 
Table 1 The average values of CS

Tablica 1. Prosječne vrijednosti tlačne čvrstoće (CS)

\begin{tabular}{|c|c|c|c|c|}
\hline \multicolumn{2}{|c|}{$\begin{array}{l}\text { Heat temperature conditions } \\
\text { Uvjeti toplinske obrade }\end{array}$} & \multirow{2}{*}{$\begin{array}{c}\text { Experimental value of CS } \\
\text { Eksperimentalne vrijednosti } \\
\text { tlačne čvrstoće } \\
\mathrm{N} / \mathrm{mm}^{2} \\
\text { Mean } \\
\text { Prosječno }\end{array}$} & \multicolumn{2}{|c|}{$\begin{array}{c}\text { Prediction value of CS by using ANN } \\
\text { Predviđene vrijednosti tlačne čvrstoće } \\
\text { primjenom ANN } \\
\mathrm{N} / \mathrm{mm}^{2}\end{array}$} \\
\hline $\begin{array}{l}\text { Time, hour } \\
\text { Vrijeme, sati }\end{array}$ & $\begin{array}{l}\text { Temperature, }{ }^{\circ} \mathrm{C} \\
\text { Temperatura, },{ }^{\circ} \mathrm{C}\end{array}$ & & $\begin{array}{c}\text { Mean } \\
\text { Prosječno }\end{array}$ & $\begin{array}{l}\text { Correct level, \% } \\
\text { Razina točnosti, \% }\end{array}$ \\
\hline 0 & 0 & 45.46 & 44.80 & 98.54 \\
\hline \multirow[t]{6}{*}{3} & 130 & 50.40 & 48.40 & 96.03 \\
\hline & 145 & 47.95 & 50.00 & 95.63 \\
\hline & 160 & 49.20 & 50.80 & 96.75 \\
\hline & 175 & 50.17 & 50.80 & 98.75 \\
\hline & 190 & 50.80 & 51.20 & 99.21 \\
\hline & 205 & 50.00 & 51.21 & 98.00 \\
\hline \multirow[t]{6}{*}{6} & 130 & 52.79 & 48.00 & 90.92 \\
\hline & 145 & 51.14 & 50.00 & 97.77 \\
\hline & 160 & 49.39 & 51.20 & 99.23 \\
\hline & 175 & 50.96 & 51.20 & 99.52 \\
\hline & 190 & 54.01 & 49.20 & 91.11 \\
\hline & 205 & 51.08 & 51.21 & 99.98 \\
\hline \multirow[t]{6}{*}{9} & 130 & 54.53 & 51.60 & 95.97 \\
\hline & 145 & 53.55 & 51.60 & 96.35 \\
\hline & 160 & 51.14 & 52.00 & 98.42 \\
\hline & 175 & 49.99 & 52.81 & 94.38 \\
\hline & 190 & 50.70 & 52.60 & 97.26 \\
\hline & 205 & 52.40 & 52.00 & 99.23 \\
\hline \multirow[t]{6}{*}{12} & 130 & 52.82 & 51.60 & 98.89 \\
\hline & 145 & 49.77 & 52.40 & 97.66 \\
\hline & 160 & 52.71 & 52.80 & 96.91 \\
\hline & 175 & 53.52 & 50.80 & 98.45 \\
\hline & 190 & 52.32 & 48.40 & 92.50 \\
\hline & 205 & 49.60 & 48.40 & 97.58 \\
\hline \multicolumn{4}{|c|}{$\begin{array}{l}\text { Current level of the average value of CS, \% } \\
\text { Trenutačna razina prosječne vrijednosti tlačne čvrstoće, \% }\end{array}$} & 97.02 \\
\hline
\end{tabular}

by using input values of heat treatment conditions and output values determined from the experimental results. Designed model is shown in Figure 1.

The aim of the network is to predict CS of test samples. The network is trained by using MATLAB neural network module (nftool). A total of $70 \%$ of these data is used for training, $15 \%$ is used for validation, $15 \%$ is used for testing. The data for each class are chosen randomlly from the total data set.

In this study, the number of neurons in the hidden layer is 25 . This number is obtained by trial and error. In the nftool nature hyperbolic tansig function $f(x)=1$ / $(1+\exp (-x))$ is applied. Input data is applied after normalization process between -1 and +1 .

\section{RESULTS AND DISCUSSION} 3. REZULTATI I RASPRAVA

The air dry density of Scots pine is $0.62 \mathrm{~g} / \mathrm{cm}^{3}$. The CS values of Scotch pine woods, obtained from experimental results, were compared with ANN model to determine the accuracy of the developed model. Our network was trained with designed data set to obtain the predicted result. Regression analysis of the training phase is given in Figure 2.
It is seen that regression coefficients obtained from training, validation and test phase of network are calculated close to 1 . This result showed that the designed model is reliable.

Based on this comparison, the developed model agreed with average test results at the accuracy level of $97.02 \%$ of CS value. Both experimental values and prediction values are given in Table 1 .

The variance analysis of CS based on heat treatment circumstances was done by using variance analysis (Table 2.). The difference between the groups regarding the effect of variance sources on CS was significant $(\alpha=5 \%)$.

It can be seen that the conditions of heat treatment has no effects on the CS values of Scotch pine wood according to variance analysis. So, the results of the Tukey test conducted to determine the importance of the differences between the groups are given in Table 3 .

It can be seen that the CS values ranged between $45.46 \mathrm{~N} / \mathrm{mm}^{2}$ and $52.29 \mathrm{~N} / \mathrm{mm}^{2}$ according to Tukey's test (Table 3 ). It can be stated that when the temperature and time of the heat treatment increase, the value of CS increases. However, the ratio of increase is not statically significant. Thus, they are put into the same homogeneous group. The change of CS values, both experimental and prediction values, are given in Figure 3. 

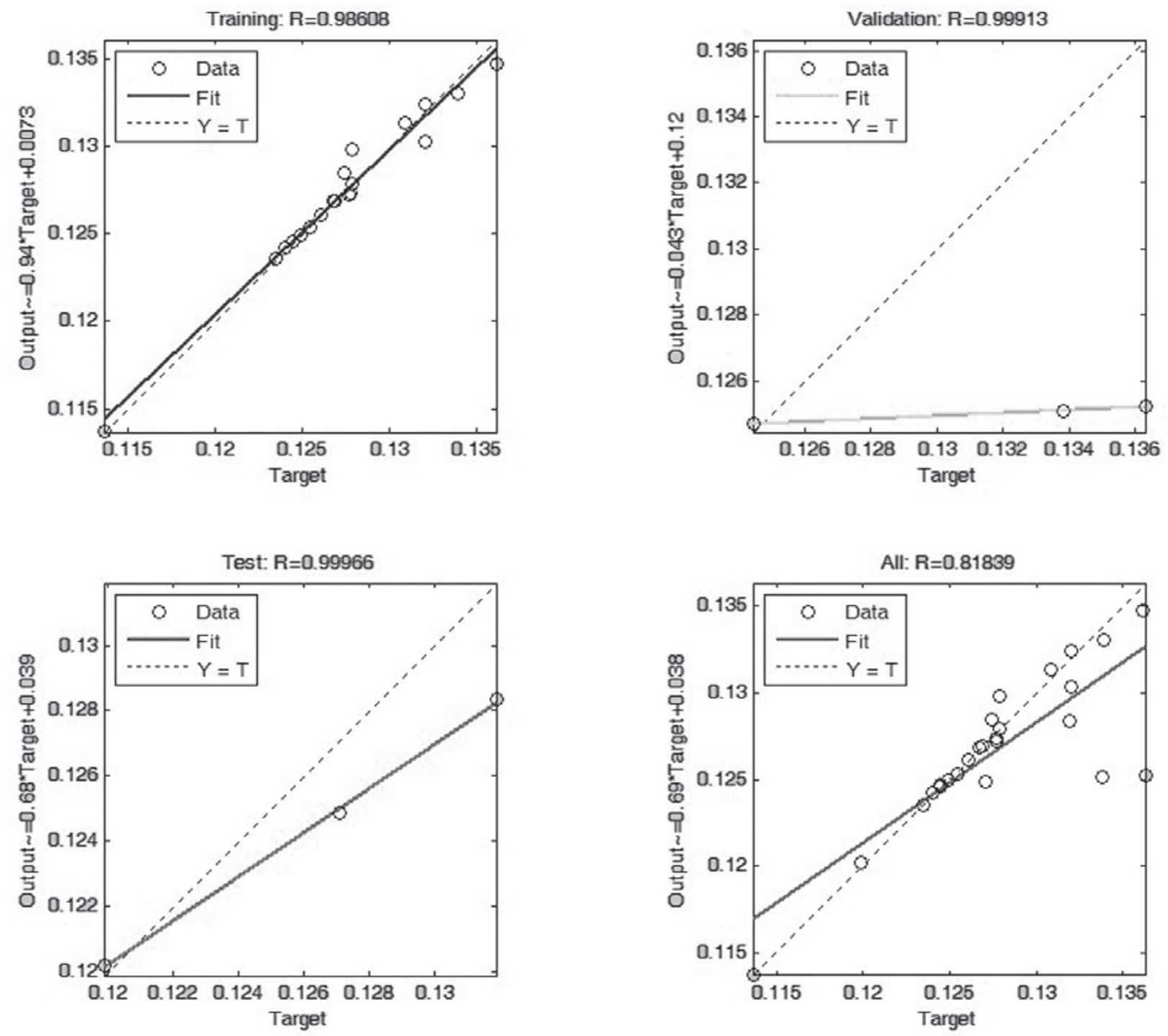

Figure 2 Network regression analyses of training

Slika 2. Regresijska analiza treniranja mreže

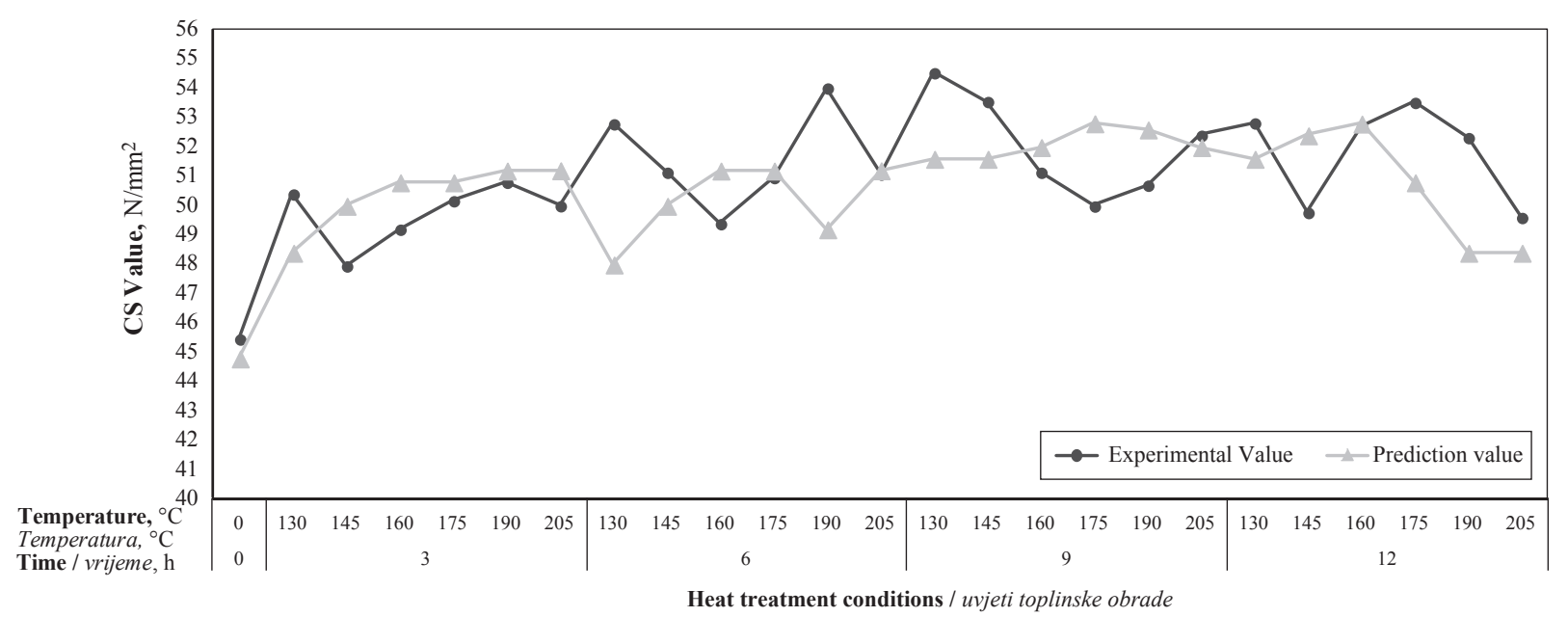

Figure 3 The change of experimental and prediction values of compressive strength

Slika 3. Promjena eksperimentalnih i predviđenih vrijednosti tlačne čvrstoće 
Table 2 Result of the variance test

Tablica 2. Rezultati testa varijance

\begin{tabular}{|l|c|c|c|c|c|}
\hline Source / Izvor & $\begin{array}{c}\text { Type III Sum of } \\
\text { Squares } \\
\text { Tip III zbroj kvadrata }\end{array}$ & Df & $\begin{array}{c}\text { Mean Square } \\
\text { Kvadrat srednje } \\
\text { vrijednosti }\end{array}$ & $\begin{array}{c}\text { F-value } \\
\text { F-vrijednost }\end{array}$ & $\begin{array}{c}\text { Sig.level } \\
\text { Razina signifikantnosti }\end{array}$ \\
\hline Corrected Model / Ispravljeni model & 1474.17 & 24 & 61.42 & 1.87 & 0.09 \\
\hline A: Time, h / vrijeme, $h$ & 159.72 & 3 & 53.24 & 1.62 & 0.18 \\
\hline B: Temperature, ${ }^{\circ} \mathrm{C} /$ temperature, $^{\circ} \mathrm{C}$ & 292.87 & 5 & 58.57 & 1.78 & 0.11 \\
\hline $\mathrm{A}{ }^{*} \mathrm{~B}$ & 529.79 & 15 & 35.31 & 1.07 & 0.37 \\
\hline Error / Pogreška & 11482.28 & 350 & 32.80 & & \\
\hline Total / Ukupno & 991349.46 & 375 & & & \\
\hline
\end{tabular}

Table3 Results of Tukey's Test

Tablica 3. Rezultati Tukeyeva testa

\begin{tabular}{|l|c|c|c|}
\hline \multicolumn{2}{|l|}{$\begin{array}{l}\text { Conditions of heat treatment } \\
\text { Uvjeti toplinske obrade }\end{array}$} & $\begin{array}{c}\text { Mean / } \\
\text { Prosječno }\end{array}$ & HG $^{*}$ \\
\hline Time, h & 0 & 45.46 & $\mathrm{~A}$ \\
\cline { 2 - 4 } & 12 & 50.31 & $\mathrm{~B}$ \\
\cline { 2 - 4 } & 6 & 51.29 & $\mathrm{~B}$ \\
\cline { 2 - 4 } & 3 & 51.44 & $\mathrm{~B}$ \\
\cline { 2 - 4 } & 9 & 52.18 & $\mathrm{~B}$ \\
\hline Temperature, ${ }^{\circ} \mathrm{C}$ Temperatura,${ }^{\circ} \mathrm{C}$ & 0 & 45.46 & $\mathrm{~A}$ \\
\cline { 2 - 4 } & 130 & 49.53 & $\mathrm{~B}$ \\
\cline { 2 - 4 } & 190 & 51.01 & $\mathrm{~B}$ \\
\cline { 2 - 4 } & 145 & 51.45 & $\mathrm{~B}$ \\
\cline { 2 - 4 } & 160 & 51.47 & $\mathrm{~B}$ \\
\cline { 2 - 4 } & 205 & 52.09 & $\mathrm{~B}$ \\
\cline { 2 - 4 } & 175 & 52.29 & $\mathrm{~B}$ \\
\hline
\end{tabular}

HG: Homogenous Group / homogena skupina

\section{CONCLUSIONS}

4. ZAKLJUČAK

Based on the results of tests, it can be said that the properties of compression strength parallel to grain were slightly affected by applying the heat treatment. It can be seen that the CS values decrease with the increase of the time and temperature of heat treatment. The values obtained from experimental work are used for artificial neural network system. CS values of test samples have been predicted by the designed model at $97.33 \%$ accuracy level. So, ANN model can be used to predict many mechanical and physical properties of wood and wood composite materials.

\section{REFERENCES}

\section{LITERATURE}

1. Arslan, O.; Kurt, O.; Konak, H., 2007: Suggestions on applications of artificial neural networks in geodesy, TMMOB Harita ve Kadastro Mühendisleri Odası, II. Türkiye Harita Bilimsel ve Teknik Kurultayı, 2-6 April, Ankara.

2. Avramidis, S.; Iliadis, L., 2005: Wood-water sorption isotherm prediction with artificial neural networks: a preliminary study. Holzforschung, 59: 336-341 http://dx.doi.org/10.1515/HF.2005.055.

3. Avramidis, S.; Iliadis, L.; Shawn, D.; Mansfield, 2006: Wood dielectric loss factor prediction with artificial neural Networks, Wood Sci Techn., 40: 563-574 http://dx.doi.org/10.1007/s00226-006-0096-3.
4. Cook, D. F.; Ragsdale, C. T.; Major, R. L., 2000: Combining a neural network with a genetic algorithm for process parameter optimization. Eng Appl Artif Intell, 13: 391-396 http://dx.doi.org/10.1016/S0952-1976(00)00021-X.

5. Cook, D. F.; Chiu, C. C., 1997: Predicting the internal bond strength of particleboard, utilizing a radial basis function neural network. Eng Appl Artif Intell, 10 (2): 171-177 http://dx.doi.org/10.1016/S0952-1976(96)00068-1.

6. Drake, P. R.; Packianather, M. S., 1998: A decision tree of neural networks for classifying images of wood veneer. Int J Adv Manuf Technol., 14: 280-285 http://dx.doi.org/10.1007/BF01199883.

7. Esteban, L. G.; Fernandez, F. G.; Palacios, P. D.; Romer, R. M.; Cano, N. N., 2009a: Artificial Neural Networks in Wood Identification: The Case of Two Juniperus Species from The Canary Islands, IAWA JOURNAL, 30 (1): $87-$ $94 \mathrm{http} / / / \mathrm{dx}$. doi.org/10.1163/22941932-90000206.

8. Esteban, L. G.; Garcia Fernandez, F.; De Palacios, P.; Conde, M., 2009b: Artificial neural networks in variable process control: application in particleboard manufacture. Invest Agrar Sist Recur For, 18 (1): 92-100 http://dx.doi.org/10.5424/fs/2009181-01053.

9. Fernández, G. F.; Esteban, L. G.; De Palacios, P.; Navarro, N.; Conde, M., 2008: Prediction of standard particleboard mechanical properties utilizing an artificial neural network and subsequent comparison with a multivariate regression model. Invest Agrar Sist Recur For, 17 (2): 178-187 http://dx.doi.org/10.5424/srf/2008172-01033.

10. Işeri, A.; Karlık, B., 2009: An artificial neural networks approach on automobile pricing. Expert Systems with Applications, Part 1, 36, 2155-2160 http://dx.doi.org/10.1016/j.eswa.2007.12.059.

11. Junior, K. J. K.; Pinto, F.; Queiroz, D. M.; De Lucia, R. M. D.; Resende, R. C., 2006: Neural networks for recognition of eucalypts lumber defects in digital images, Scientia Forestalis, 70: 85-96.

12. Kamdem, D. P.; Pizzi, A.; Jermannaud, A., 2002: Durability of heattreated wood. Holz als Roh-und Werkstoff, 60: 1-6 http://dx.doi.org/10.1007/s00107-001-0261-1.

13. Khalid, M.; Yi, L. E.; Yusof, R.; Nadaraj, M., 2008: Design of an Intelligent Wood Species Recognition System, International Journal of Simulation: Systems, Science \& Technology, 9 (3).

14. Korkut, S.; Kok, M. S.; Korkut, S. D.; Gurleyen, T., 2008: The effects of heat treatment on technological properties in Red-bud maple (Acer trautvetteri Medw.) wood. Bioresource Technology, 99: 1538-1543 http://dx.doi.org/10.1016/j.biortech.2007.04.021.

15. Long, W.; Rice R. W., 2008: Detection of Structural Damage in Medium Density Fiberboard Panels using Neural Network Method. Journal of Composite Materials, 42: 1133-1145 http://dx.doi.org/10.1177/0021998308090455. 
16. Mazela, B.; Zakrzewski, R.; Grzes'kowiak, W.; Cofta, G.; Bartkowiak, M., 2004: Resistance of thermally modified wood to basidiomycetes. Wood Technology, 7 (1): 253-262.

17. Militz, H., 2002: Thermal treatment of wood: European processes and their background. IRG/WP 02-40241, 33rd Annual Meeting, 12-17 May, Cardiff-Wales 4, pp. 1-17.

18. Samarasinghe, S.; Kulasiri, D.; Jamieson, T., 2007: Neural Networks for predicting fracture toughness of individual wood samples. Silva Fennica, 41 (1): 105-122 http://dx.doi.org/10.14214/sf.309.

19. Sha, W., 2007: Comment on the issues of statistical modelling with particular reference to the use of artificial neural networks. Appl Catal A-Gen, 324: 87-89 http:// dx.doi.org/10.1016/j.apcata.2007.02.053.

20. Shawn, D.; Mansfield; Iliadis, L.; Avramidis, S., 2007: Neural network prediction of bending strength and stiffness in western hemlock (Tsuga heterophylla Raf.). Holzforschung, 61 (6): 707-716.

21. Tanaka, T.; Nagao, H.; Ve Kato, H., 1996: A preliminary investigation on evaluation of strength of soft wood timbers by neural network, 10th international symposium on nondestructive testing of wood, August 26-28, pp. 323329.

22. ***TS 2595 , Wood-determination of ultimate stress in compression parallel to grain, 2005, TSE, Ankara.
23. Tou, J. Y.; Lau, P. Y.; Tay, Y. H., 2007: Computer Visionbased Wood Recognition System, Proceedings of International Workshop on Advanced Image Technology (IWAIT), January, Bangkok, Thailand, pp.197-202.

24. Xu, Xu.; Yu, Zi-Tao.; Hu, Ya-Cai.; Fan, Li-Wu.; Tian, Tian.; Cen, Ke-Fa., 2007: Nonlinear fitting calculation of wood thermal conductivity using neural Networks. Zhejiang University Press, 41 (7): 1201-1204.

25. Yapıc1, F.; Ozcifci, A.; Akbulut, T.; Bayir, R., 2009: Determination of modulus of rupture and modulus of elasticity on flakeboard with fuzzy logic classifier. Materials and Design, 30: 2269-2273

http://dx.doi.org/10.1016/j.matdes.2008.09.002.

\section{Corresponding address:}

Prof. FATIH YAPICI, Ph.D.

Ondokuz Mayıs University

Engineering Faculty

Department of Industrial Engineering

Samsun 55139, TURKEY

e-mail: fatih.yapici@omu.edu.tr 